\title{
Assessing biodiversity in arable farmland by means of indicators: an overview
}

\author{
Christian BOCKSTALLER \\ Françoise LASSERRE-JOULIN \\ Sophie SLEZACK-DESCHAUMES \\ Séverine PIUTTI \\ Jean VILLERD \\ Bernard AMIAUD \\ Sylvain PLANTUREUX
}

INRA, UMR 1121

Nancy-Université - INRA,

IFR 110, Nancy-Colmar,

BP 20507, 68021 Colmar

France

<christian.bockstaller@colmar.inra.fr>

Maintaining biodiversity is one of the key issues of sustainable development, and agriculture is highly concerned in this perspective. The term was first suggested in 1985 at a conference on biological diversity in the USA and was popularized since the Rio Conference in 1992 (Le Guyader, 2008). It is now commonly accepted that biodiversity can address the biological diversity at different levels: i) the compositional, including the genetic, species, community, habitat diversity, ii) the structural, iii) the functional encompassing processes within that level (Clergue et al., 2005). In the 2000s, the Millennium Ecosystems Assessment (2005) introduced the concept of ecosystemic services provided by biodiversity, like pollination, and pest control.

In arable area the change in land use, the intensification and simplification of cropping systems, as well as the drastic reduction of semi-natural elements (hedges, trees, wet zones, etc.) have led to a significant decrease of biodiversity in arable land (Le Roux et al., 2008). Different options were developed to mitigate negative effect of agriculture

\begin{abstract}
Maintaining biodiversity is one of the key issues of sustainable agriculture. It is now stated that innovation to enhance biodiversity in arable land requires operational assessment tools like indicators. The goal of the article is to provide an overview of available indicators. Besides measured indicators and simple indicators based on management data, we focus on predictive indicators derived from operational models and adapted to ex ante assessment in innovative cropping design. The possibility of use for each indicator type is discussed.
\end{abstract}

Key words: environmental assessment, indicator, model, validation, biodiversity, ecosystemic services

intensification, among them extensification and even suppression of chemical input like in organic farming (Hole et al., 2005), reconsideration of field margin management to enhance semi-natural area of farmland (Marshall and Moonen, 2002). It is now stated that this process of innovation to enhance biodiversity in arable land requires operational assessment tools. These tools should evaluate the current state at different scales, identify the causes of biodiversity impoverishment in a diagnosis phase, and assess the effects of innovative solution cropping systems (Bockstaller et al., 2008b). This led many authors to plead for research on biodiversity indicators (Carpenter et al., 2006) which have not to be confounded with bioindicators (Duelli and Obrist, 2003). The latter use a component of biodiversity to assess something else, like the accumulation of a pollutant.

From a general point of view, the term "indicator" can refer to many definitions (Heink and Kowarik, 2010) as shown in figure 1 (Bockstaller et al., 2008b). Those authors set a typology based on the nature of the indicators.
Indicators can be basic variables (e.g. amount of input) or simple combination of these variables (balance, ratio) as well as field measurements, the former being also called "indirect" and the latter "direct" indicator regarding biodiversity (Burel et al., 2008). Indicators can also be derived from model outputs and thus can be considered as "predictive indicators". By this way, an indicator can be obtained from the average of model output, transformed into scores or even expressed as the ratio of a model output and a reference value, as for pesticide risk indicators (Bockstaller et al., 2009). This type of indicators expresses an explicit link between input variables addressing the causes, and an output reflecting an effect on environment. Models can be roughly separated in operational models using a limited and available set of input variables and complex models which are too difficult to implement by non-scientists. If measured indicators are totally relevant for ex post assessment of the state of biodiversity to evaluate e.g. the results of agri-environmental scheme (Kleijn et al., 2006), they

To cite this article: Bockstaller C, Lasserre-Joulin F, Slezack-Deschaumes S, Piutti S, Villerd J, Amiaud B, Plantureux S. Assessing biodiversity in arable farmland by means of indicators: an overview. OCL 2011;18(3):137-44. doi : 10.1684/ocl.2011.0381 


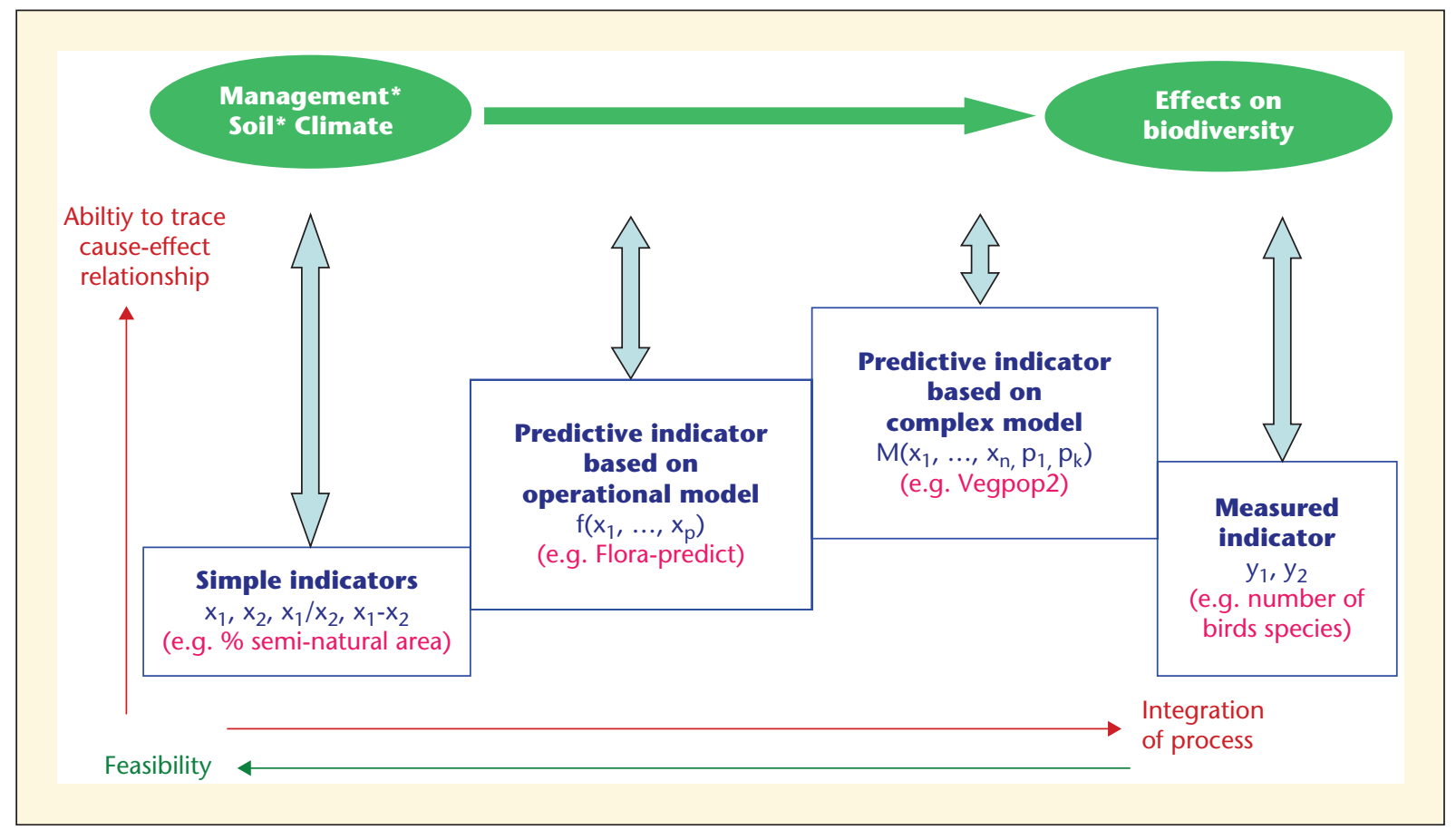

Figure 1. Typology of indicators base on the construction method and evaluation of their quality (inspired from Bockstaller et al., 2008b)

do not allow trace the cause. Simple indicators can complete the information on the causes or "pressure". Predictive indicators offer a compromise between simple indicators and measured indicators regarding feasibility and degree of integration of process. They can be used for ex ante assessment to predict effect of simulated system. Such indicators are necessary for agronomist working on innovative cropping design (Sadok et al., 2008).

Since the 90s, scientific publications on biodiversity indicators have increased to reach 100 articles per year in the last years (Burel et al., 2008). In the last decade, several reviews were published but their scope was beyond agriculture addressing natural land (e.g. Levrel, 2007). Others focused on agriculture but covered only measured indicators and secondary simple indicators derived from management data (Braband et al., 2003; Büchs et al., 2003; Delbaere, 2003; Burel et al., 2008). Clergué et al. (2005) gave two examples of models which can be used to derive indicators: Vegepop2 a complex model predicting the effect on field boundary flora and Flora-predict (Amiaud et al., 2005), an operational model for meadow flora. The model Vegpop2 predicts a dynamic of biomass for different species that allows assess the biodiversity, whereas the operational model Flora-Predic provides a probability of presence. This output only indicates the occurrence of species and can be considered as an indicator. This last group of predictive biodiversity indicators remains poorly covered by scientific literature. In this article, we aimed at providing an overview of the available biodiversity indicators covering the three types of indicators, with a focus on this last group of predictive indicators. We illustrate it with recent initiatives concerning predictive indicators addressing biodiversity for different taxa mainly plants, invertebrate and soil microbial communities, this for spatial scale ranging from field to agricultural landscape.

\section{Measured (direct) indicators}

Since the $80 \mathrm{~s}$, a vast number of measured indictors were proposed in the literature as previously reviewed by Noss (1990) and more recently by Lindenmayer and Likens (2011). Indicators based on species diversity and/or abundance among a given taxon or several taxa (e.g. birds, plants, carabid beetles, etc.) are the most commonly indicators used at different scale from field to national level. An exhaustive review of proposals for different taxa can be found in Burel et al. (2008). Species of almost all taxonomic groups have been proposed (Lindenmayer and Likens, 2011). The indicator may address all the species of a given taxon or a given category like the number threatened species given by the Red Lists for a given region (see list given by Delbaere (2003)). It can also focus on the diversity of keystone species, i.e. a species supporting the functioning of a ecosystem and the survival of many other species as well as umbrella species, i.e. species which needs a large area to survive and offers possibility of existence to many other species (Clergué et al., 2005). However examples of such specific species are scarce in agriculture.

In field experiments testing new designed cropping systems, agronomist assessed biodiversity by some measured indicators like plant diversity (Vereijken, 1997; Pacini et al., 2003). Among invertebrates, indicator based on the diversity of carabid beetle were proposed by many authors because they are relatively easy to assess by simple pitfall although they were criticized as indicator of biodiversity (Duelli, 1997). Döring and Kromp, 2003 analysed the 
ability of different carabid beetle species to indicate the impact of change of cropping systems from intensive to organic.

At smaller level, soil is one of the major reservoirs of microbial diversity, one gram of soil containing between 3,000 and 11,000 genomes (Torsvik and Ovreas, 2002). Nevertheless, assessing the diversity (in terms of species number) remained a challenge for microbial ecologists, traditional techniques based on isolation and culturing being too selective (Gardi et al., 2009). Molecular techniques like fingerprinting based on $16 S$ rDNA sequences were commonly used to reveal patterns considered as "a picture" of the microbial communities. Nevertheless, the evaluation of the microbial specific diversity is poorly informative in relation to soil functioning (Maron et al., 2011). Therefore molecular techniques targeting key microbial genes implicated in ecosystem functions were valuable tools to assess functional diversity (genetic structure, abundance vs level of expression of functional microbial genes). The development of multiparametric indices integrating these data is now needed to better understand the relationships between soil microbial diversity and function.

At higher scale, only one indicator is currently available in France at present time: the diversity and abundance of common birds (about 120 species) which are divided in generalists, farmland, forest and urban areas. Results of the assessment over more than 10 years show a clear decline in farmland specialists. The strength of this indicator is that is can be relatively easy to obtain, species being easy to determine, easy to interpret, the cause of variation being

Table 1. Example of composite indices of biodiversity

\begin{tabular}{|c|c|}
\hline Indicator & Méthode de calcul \\
\hline Species number & $\begin{array}{l}S=\Sigma s_{i} \\
\text { avec } s_{i}: i^{\text {th }} \text { species }\end{array}$ \\
\hline Shannon Index & $\begin{array}{l}\mathrm{H}^{\prime}=-\Sigma \mathrm{p}_{\mathrm{i}} \cdot \operatorname{Ln} \mathrm{p}_{\mathrm{i}}{ }^{(\mathrm{a})} \\
\text { with } \mathrm{p}_{\mathrm{i}}=\text { proportion of species } \mathrm{i}(\text { entre } 0 \text { et } 1)\end{array}$ \\
\hline Evenness & $\mathrm{E}=\mathrm{H}^{\prime} / \operatorname{Ln} \mathrm{S}$ \\
\hline Simpson's Index & $\mathrm{D}=\Sigma \mathrm{p}_{\mathrm{i}}^{2}$ \\
\hline Reciprocal Simpson's index & $1 / D$ \\
\hline Buckland arithmetic Occurrence index: & $\begin{array}{l}\text { BuckArith-Ol= } \\
100 / S \Sigma O_{i} / R_{i} \\
\text { with } O_{i}=\text { site number where species } i \text { is observed } \\
R_{i}=\text { site number where species } i \text { was observed }\end{array}$ \\
\hline
\end{tabular}

well know, and present a power of communication to the society (Levrel, 2007).

Since diversity cannot be only be reduced to the number of species but also to their abundance and evenness in distribution, several composite indices were proposed, to go further than the species number. Table 1 shows some examples but more can be found in Magurran (2004) who supplied information about their statistical relevance. Among them, the Shannon index is one the most popular one although some authors criticized its statistical relevance and do not consider it as a true diversity index but as an entropy evaluation (Jost, 2006). The reciprocal Simpson's indicator is a real diversity indicator and its outputs can be more easily interpreted: It is equal to the species number in case of even distribution of species (all species have the same percentage in the sample) and decreases with increase of unevenness. It highlights the number of dominant species in a certain way. In any case, no single index can provide all the information directly. Our proposal is to implement simultaneity a composite index like the reciprocal Simpon's indicator, and at least two other indices to explain the former, like the number of species and an the evenness index.

\section{Simple (indirect) indicators based on management data}

Many proposals also exist for this type of indicators. Among the 91 indicators listed for agriculture by Delbaere (2003) more than the half belongs to this type. Considering the general model explaining biodiversity in farm- land (Le Roux et al., 2008) we classify them in two groups: i) indicators related to management of farmland at different scales ii) indicators addressing cropping practices, which can be expressed in amount of inputs per area unit or in percentage of area disturbed by fertilizer, pesticides, irrigation, tillage, both being expressed at different scales. Table 2 gives some examples used in different assessment methods (Bockstaller et al., 2008a; Bockstaller et al., 2009) and information about their validation. By validation we mean here correlation studies between indicator output and measurement of diversity for different taxa. We used data from the work of Billeter et al. (2008).

\section{Predictive indicators based on model}

Like for other environmental issues (e.g. nitrate leaching), researchers developed mechanistic models to predict the dynamic of population for a given species, its survival probability, and ecological process like predator-prey interaction. They worked mainly in ecology for natural area (Guisan and Zimmermann, 2000) with mechanistic models and also operational static models (Gontier et al., 2006) but few concerned farmland. Besides the Vegepop2 model for field boundary flora (see above Clergué et al., 2005), another model covering a species of farmland, the Corn Bunting deserves attention but remains relatively complex, needing spatial data (Meyer et al., 2007).

However in recent years, some operational approaches were developed with the specific objective to assess the effect of farmland and crop management on biodiversity as shown in table 3. Most of the methods were developed in frame of a multicriteria assessment (excepted Sanderson et al., 1995; Keichinger, 2001; Butler et al., 2009). SALCAbd (Jeanneret et al., 2006) was developed to complete the SALCA method based on life cycle analysis. Actually this biodiversity component does not tackle the whole production cycle but only the farm level like the other methods presented in table 3 . Indicators of this group provide output in form of a probability of presence for one or a reduced number of species, or in form of risk or impact scores. Whereas some models tackle in a explicit way a broad 
Table 2. Example of simple indicators used in environmental methods (Bockstaller et al., 2008a) or proposed in initiative (e.g. IRENA at EU level (EEA, 2005))

\begin{tabular}{|c|c|c|c|c|}
\hline Indicator & Unit & $\begin{array}{l}\text { Example of method } \\
\text { using the indicator, } \\
\text { or list containing it }\end{array}$ & Scale & $\begin{array}{l}\text { Validation (correlation } \\
\text { with given taxon) }\end{array}$ \\
\hline $\begin{array}{l}\text { Percentage of area cropped } \\
\text { in organic farming }\end{array}$ & $\%$ & IRENA & Region, country & $n s^{b}$ \\
\hline $\begin{array}{l}\text { Percentage of area with } \\
\text { agri-environmental scheme }\end{array}$ & $\%$ & IRENA & Region, country & $\mathrm{ns}^{\mathrm{b}}$ \\
\hline $\begin{array}{l}\text { Percentage of } \\
\text { semi-natural area }\end{array}$ & $\%$ & DIALECTE, IDEA & $\begin{array}{l}\text { Farm, landscape, } \\
\text { region, country }\end{array}$ & $\begin{array}{l}\text { Herbs, birds, bees, bugs, } \\
\text { hoverflies, carabids, } \\
\text { spiders, }\end{array}$ \\
\hline Habitat diversity & None & & $\begin{array}{l}\text { Farm, landscape, } \\
\text { region, country }\end{array}$ & Bees \\
\hline $\begin{array}{l}\text { Percentage of area with } \\
\text { high value nature }\end{array}$ & $\%$ & IRENA, KUL ${ }^{c}$, REPRO $^{c}$ & farm-landscape & Not studied \\
\hline Hedgerow length in farm & $m$ & RAD & Farm, landscape & Not studied \\
\hline $\begin{array}{l}\text { Percentage of well-managed } \\
\text { hedgerows }\end{array}$ & $\%$ & Projet OTPA & Farm, landscape & $\mathrm{ns}^{\mathrm{b}}$ \\
\hline Median size of field & ha & $\mathrm{KUL}^{\mathrm{c}}, \mathrm{REPRO}^{\mathrm{c}}$ & Farm, landscape & $\mathrm{ns}^{\mathrm{b}}$ \\
\hline $\begin{array}{l}\text { Average number of } \\
\text { crops per farm }\end{array}$ & none & & Farm, landscape & Bees, bugs, carabids \\
\hline Crop diversity & $\begin{array}{l}\text { None (Shannon } \\
\text { index }\end{array}$ & $\mathrm{KUL}^{\mathrm{c}}, \mathrm{REPRO}^{\mathrm{c}}$ & Farm, landscape & $n s^{b}$ \\
\hline $\begin{array}{l}\text { Percentage of area } \\
\text { cropped intensively }\end{array}$ & $\%$ & & Farm, landscape & $n s^{b}$ \\
\hline Pesticide use & $\begin{array}{l}\text { Number of } \\
\text { treatments/ha, }\end{array}$ & & & \\
\hline $\mathrm{g}$ of active ingredient/ha & & Fields, farm, landscape & No correlation & \\
\hline Pesticide use & $\begin{array}{l}\text { Treatment } \\
\text { frequency index }\end{array}$ & $\begin{array}{l}\text { DIALECTE, IDEA, KUL' } \\
\text { REPRO }^{c}\end{array}$ & Fields, farm, landscape & $\mathrm{ns}^{\mathrm{b}}$ \\
\hline $\begin{array}{l}\text { Percentage of non } \\
\text { sprayed area }\end{array}$ & $\%$ & DIALECTE, & Farm, landscape & $n s^{b}$ \\
\hline Nitroen fertilizer use & $\mathrm{kg} \mathrm{N} / \mathrm{ha}$ & & Fields, farm, landscape & Birds \\
\hline $\begin{array}{l}\text { Percentage of intensively } \\
\text { fertilized area }\end{array}$ & $\%$ & DIALECTE, IDEA & Fields, farm, landscape & Herbs \\
\hline $\begin{array}{l}\text { Percentage of } \\
\text { irrigated area }\end{array}$ & $\%$ & DIALECTE, IDEA & Fields, farm, landscape & $\mathrm{ns}^{\mathrm{b}}$ \\
\hline
\end{tabular}

${ }^{a}$ see Billeter et al. (2008). Correlations studies included herbs, woody plants, birds, bees, bugs, hoverflies, carabids, spiders

${ }^{\mathrm{b}}$ not studied in Billeter et al. (2008)

c German methods (see Bockstaller et al. (2009))

number of species, for plants (Sanderson et al., 1995) or severa taxa (Butler et al., 2009), most them focus on a few number of species or few taxa without explicit information on species. The IBEA method (Anonymous., 2011) does not address the species level but only biodiversity in general through an "environment quality" and a "genetic diversity" components.

Behind the calculation of such predictive indicators, different aggregation approaches are used: scoring systems based on equations (Sanderson et al., 1995; Jeanneret et al., 2006; Butler et al., 2009) or functions (MeyerAurich et al., 2003), decision tree using fuzzy subsets allowing cope with uncertainty and avoid effect of knife-edge limit of classes (Keichinger, 2001; Sattler et al., 2010). More recently several authors (Sadok et al., 2009; Messéan et al., 2010; Anonymous., 2011)) developed a qualitative approach based on decision tree using the DEXi tool (Bohanec et al., 2008). Tichit et al. (2010) worked on a totally different approach, using a dataset and deriving a posteriori regressions between a variable assessing the occurrence of bird and different sets of input variables (table 3).

\section{Discussion}

This article aimed at providing an overview of the biodiversity indicator available to agronomists working on cropping systems at field and to other stakeholders working on higher scales. 


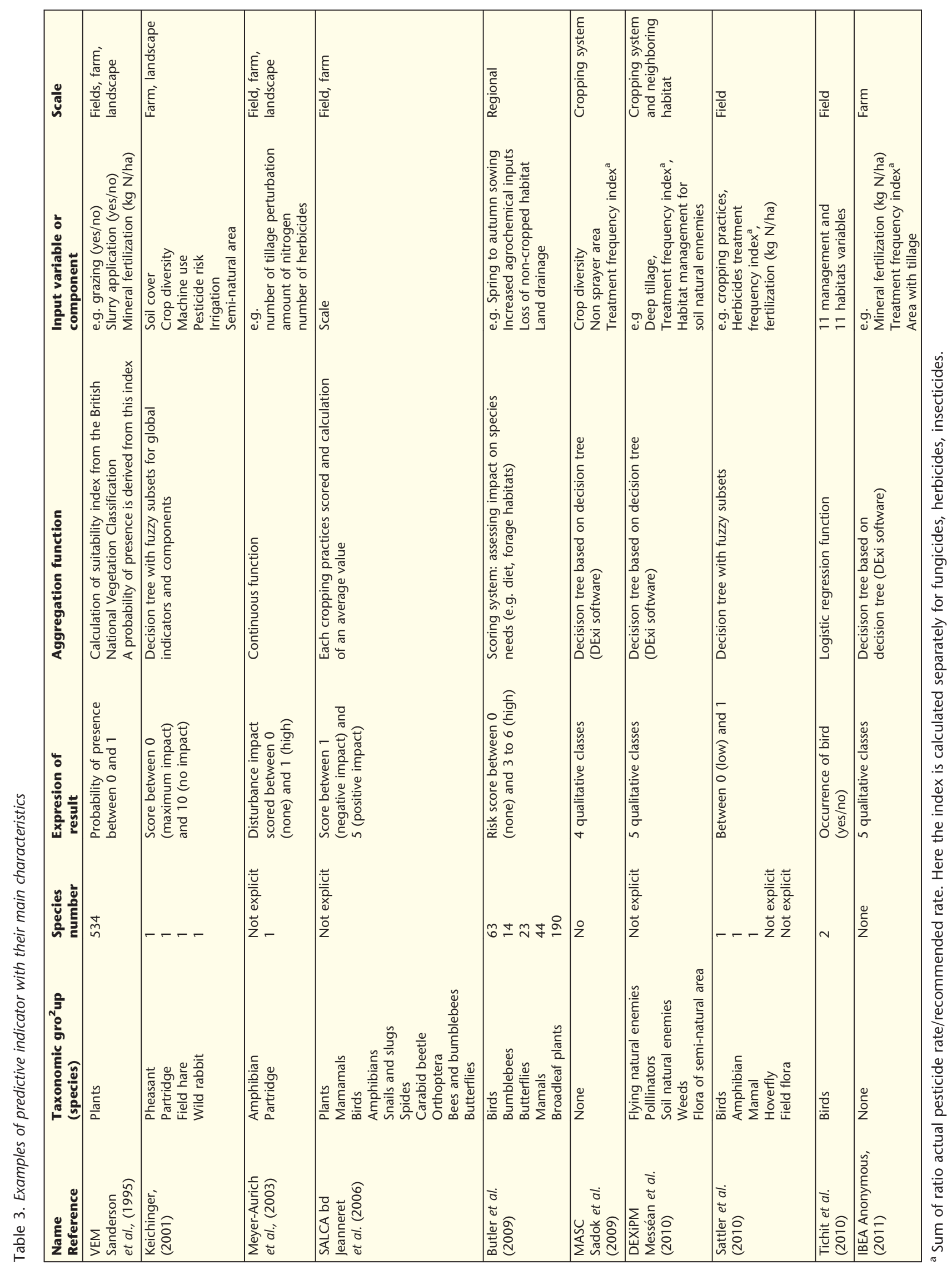

OCL VOL. $18 \mathrm{~N}^{\circ} 3$ mai-juin 2011 
We organized the presentation in three groups of indicators according to their type of construction. As it was pointed out by several review articles, a very large number of measured indicators are available using many taxonomic groups. The implementation of such indicators requires taxonomic knowledge what is the main hindrance to their implementation for non-specialists like many agronomists. This led some authors to propose parataxonomic approach which assess the diversity by sorting living organisms into morphologic groups (Duelli and Obrist, 2003). This approach remains very controversial (Abadie et al., 2008). Lindenmayer and Likens (2011) analysed in a very exhaustive way the use of measured biodiversity indicator. They pointed out the lack of justification for the choice of the species and the poor predictive quality of many measured indicators. Some authors tried to validate measured indicators. At European level no group species could be correlated to the diversity of all taxa (Billeter et al., 2008), although such test across different ecosystems is not relevant according Lindenmayer and Likens (2011). At field level, a comparison of individual taxa of invertebrates with the whole diversity of invertebrates accross taxa yielded the best correlation for heteroptera and aculate hymnoptera (bees, wasp and ants), (Duelli and Obrist, 2003). Arena, coleotera (among them carabid beetles), syrphidae or red list species showed a poor correlation.

Such considerations led several authors to state that assessment of biodiversity should rest on several taxa (e.g. Carignan and Villard, 2002; Duelli and Obrist, 2003). In any case, biodiversity indicators are often expressed in composite indices like those presented in table 1. The Shannon indicator is the most popular but does not seem to be the most relevant (Jost, 2006). A major drawback is that such indicators are only quantitative and do not take into account the nature of species. An increase of biodiversity can also be due to invasive species (Lamb et al., 2009). Those authors tested the ability of several indices to show changes of biodiversity. Traditional indices like the Simpson and Shannon indices (see table 1) yielded poorly in comparison with the Buckland arithmetic Occurrence index. In the approach of van Wenum et al. (1999) in the Netherlands, which assesses biodiversity at farm level, each species is weighted by a factor addressing its rarity.

Although there is a growing agreement to assess not only biodiversity but also the linked ecosystemic services like pollination (Le Roux et al., 2008), those are assessed in very indirect way by assessing the diversity of species involved in the service. This is the case for biological control. But possibility of predation between predator guilds limits the interest of species diversity, which is a very complex concept (Straub and Snyder, 2008). Measurement of amount of captured prey by a predators, or determination of stomach content of predator with help of molecular biology (King et al., 2008) are useful to assess the service in experimental conditions. The implementation of such techniques in routine to derive an indicator remains questionable for the moment.

The second group of simple indicators based on management variable are more easy to assess than measured ones and are therefore used in several multithematic environmental assessment method (Braband et al., 2003). Their predictive quality remains in general poor although Billeter et al. (2008) found some correlations with the diversity of some taxa (table 2). But the correlations were observed for a very broad range of conditions regarding landscape structures, farming systems. Such indicators do not take into account interactions between management and pedo-climatic conditions and do not refer in an explicit way to species. In any case, simple indicators based on management data are useful to communicate with farmers as they focus on information which farmers know and understand (Tichit et al., 2010). They can be used to analyze results obtained with measured indicators. The Nature Balance is an example of assessment method of biodiversity at farm level combining both types of indicators (Oppermann, 2003).

In the difference with previous reviews on biodiversity indicators in farmland (e. g. Braband et al., 2003; Büchs et al., 2003), our article does not only focus on measured indicators or simple indicators using management data, but also on predictive indicators. In the last decade several initiatives were proposed for assessment of agricultural systems, a majority of them being developed in the frame of multi-criteria assessment method addressing also other environmental issues or even other dimensions of sustainability. Their advantage is that they do not need taxonomic identification while providing information of impacts of crop management factors on one or several species, or a given taxon. Most of them can be used by agronomists working on design of innovative cropping systems.

Like for the other types of indicators, their predictive quality remains a question. Correlations were found by some authors between indicator output and measured diversity of the taxon (Butler et al., 2009, excepted for broadleaf species), at the level of occurrence of species (Sanderson et al., 1995), or with expert judgments (Keichinger, 2001). The development of qualitative approach based on the DEXi tool (Bohanec et al., 2008) should be noticed. The construction of such qualitative models is relatively easy but the methodology requires more methodological investment, especially on the sensitivity (Bergez et al., 2010). No validation was undertaken for these methods based on DEXi. Actullay such indicators constructed with expertbased methods may be limited by uncertainty and subjectivity. While expert-based indicators are built in a "top-down" manner, a new trend consists in adopting a "bottom-up" point of view by building indicators from observation data. The approach of Tichit et al. (2010) is one option. Machine-learning techniques (Shan et al., 2006) such as decision trees is another. They allow produce indicators that are more objective, scientifically sound and still easy to interpret. Uncertainty is still present but can be represented and handled using accurate formalisms such as fuzzy logic. A work on the development of a biological control indicator is ongoing within the Casdar entomophage project (2009$2011)^{1}$. The availability of adequate dataset is a major requirement for the development of indicators following this methodology.

\section{Conclusion}

A vast number of biodiversity indicators are currently available for the agrono-

\footnotetext{
${ }^{1}$ http://78.155.145.122/rmtbiodiv/moodle/course/category.php?id=21.
} 
mist and stakeholders who needs to assess the impact of agriculture on biodiversity. A great diversity of indicators goes together with this abundance. The selection of indicators among the three types of indicators given by the typology proposed in this article, will depend on the goal of the assessment work. We recommend to use measured indicators when users aim at assessing efficacy of a policy, of an agri-environmental scheme. But this requires several species to give a "whole picture" and a justification of the species choice. Simple indicators can be used by farmers' advicers in a first stage to work with farmers to make them aware of the problem. They can also complete the information given by measured indicators. But it remains a challenge to prove the link between both type of indicators, to highlight the causes of the observed impacts on biodiversity. The third option is to use predictive indicators resulting from an operational model or assessment function linking causes and effect. They are useful for agronomists working on ex ante assessment of newly designed cropping systems or to test policy options. Finally, more research is necessary on the validation of all those reviewed biodiversity indicators. There is also a need of new indicators assessing not only diversity per se but also the impact of crop and landscape management on ecosystemic services.

\section{REFERENCES}

Abadie JC, Andrade C, Machon N, et al. On the use of parataxonomy in biodiversity monitoring: a case study on wild flora. Biodivers Conserv 2008; 17: 3485-500.

Amiaud B, Pervanchon F, Plantureux S. An expert model for predicting species richness in grasslands: Flora-predict. In: Lillak, $\mathrm{R}$, Viiralt, R, Linke, A, Geherman, V (Eds.), 13th International Occasional Symposium of the European-Grassland-Federation, Tartu (Estonia), 2005.

Anonymous. Un outil de diagnostic de l'impact des pratiques agricoles sur la biodiversite : Outil "IBEA ». In : Impact des pratiques agricoles sur la Biodiversité des Exploitations Agricoles. FNE, INRA, MNHN, Paris, 2011.

Bergez JE, Carpani M, Monod H, et al. Sensitivity analysis of DEXi type models applied to design cropping systems. In : Wery J, Shili-Touzy I, Perrin A, (Eds). Agro
2010 the XIth ESA Congress. Montpellier (France): Agropolis International Editions, 2010.

Billeter R, Liira J, Bailey D, et al. Indicators for biodiversity in agricultural landscapes: a panEuropean study. J Appl Ecol 2008; 45: 141-50.

Bockstaller C, Galan MB, Capitaine M, et al. Comment évaluer la durabilité des systèmes en production végétale ? In: Reau, $R$, Doré, $T$ (Eds.), Systemes de culture innovants et durables: quelles méthodes pour les mettre au point et les évaluer. Educagri, Dijon (France), 2008a.

Bockstaller C, Guichard L, Keichinger O, et al. Comparison of methods to assess the sustainability of agricultural systems. A review. Agron Sustain Dev 2009; 29: 223-35.

Bockstaller C, Guichard L, Makowski D, et al. Agri-environmental indicators to assess cropping and farming systems. A review. Agron Sustain Dev 2008b; 28: 139-49.

Bohanec M, Messean A, Scatasta S, et al. A qualitative multi-attribute model for economic and ecological assessment of genetically modified crops. Ecol Model 2008; 215: 247-61.

Braband D, Geier U, Kopke U. Bio-resource evaluation within agri-environmental assessment tools in different European countries. Agric Ecosyst Environ 2003; 98: 423-34.

Büchs W, Harenberg A, Zimmermann J, et al. Biodiversity, the ultimate agri-environmental indicator? Potential and limits for the application of faunistic elements as gradual indicators in agroecosystems. Agric Ecosyst Environ 2003; 98: 99-123.

Burel F, Garnier E, Amiaud B, et al. Chapitre1. Les effets de l'agriculture sur la biodiversité. In: Le Roux X, Barbault R, Baudry J, Burel F, Doussan I, Garnier E, Herzog F, Lavorel S, Lifran R, Roger-Estrade J, Sarthou J-P, M. T (Eds.), Agriculture et biodiversité. Valoriser les synergies. Expertise scientifique collective, synthèse du rappport, INRA (France), 2008.

Butler SJ, Brooks D, Feber RE, et al. A crosstaxonomic index for quantifying the health of farmland biodiversity. I Appl Ecol 2009; 46: 1154-62.

Carignan V, Villard MA. Selecting indicator species to monitor ecological integrity: A review. Environ Monit Assess 2002; 78: 45-61.

Carpenter SR, DeFries R, Dietz T, et al. Millennium Ecosystem Assessment: Research needs. Science 2006; 314: 257-8.

Clergué B, Amiaud B, Pervanchon F, et al. Biodiversity: function and assessment in agricultural areas. A review. Agron Sustain Dev 2005; 25: 1-15.

Delbaere B. An inventory of biodiversity indicators in Europe, 2002. European Environment Agency (EEA), Copenhagen, 2003.
Döring TF, Kromp B. Which carabid species benefit from organic agriculture? - a review of comparative studies in winter cereals from Germany and Switzerland. Agric Ecosyst Environ 2003; 98: 153-61.

Duelli P. Biodiversity evaluation in agricultural landscapes: An approach at two different scales. Agric Ecosyst Environ 1997; 62: 81-91.

Duelli $\mathrm{P}$, Obrist MK. Biodiversity indicators: the choice of values and measures. Agric Ecosyst Environ 2003; 98: 87-98.

EEA. Agriculture and environment in EU-15; the IRENA indicator report. European Environmental Agency (EEA), Copenhagen (Danemark), 2005.

Gardi C, Montanarella L, Arrouays D, et al. Soil biodiversity monitoring in Europe: ongoing activities and challenges. Eur / Soil Sci 2009; 60: 807-19.

Gontier M, Balfors B, Mortberg U. Biodiversity in environmental assessment - current practice and tools for prediction. Environ Impact Assess Rev 2006; 26: 268-86.

Guisan A, Zimmermann NE. Predictive habitat distribution models in ecology. Ecol Model 2000; 135: 147-86.

Heink U, Kowarik I. What are indicators? On the definition of indicators in ecology and environmental planning. Ecol Indic 2010; 10: 584-93.

Hole DG, Perkins AJ, Wilson JD, et al. Does organic farming benefit biodiversity? Biol Conserv 2005; 122: 113-30.

Jeanneret $P$, baumgartner $D$, Freiermuth $R$, et al. Méthode d'évaluation de l'impact des activités agricoles sur la biodiversité dans les bilans écologiques. Salca bd. Agroscope FAL Reckenholz, Zurich, 2006.

Jost L. Entropy and diversity. Oikos 2006; 113 : 363-75.

Keichinger O. Evaluation de I'impact des pratiques agricoles d'exploitations de grandes cultures sur la valeur cynégétique à I'aide d'indicateurs agro-ecologiques. Doctorat INPL-ENSAIA, Nancy, 2001.

King RA, Read DS, Traugott $M$, et al. Molecular analysis of predation: a review of best practice for DNA-based approaches. $\mathrm{Mol}$ Ecol 2008; 17: 947-63.

Kleijn D, Baquero RA, Clough Y, et al. Mixed biodiversity benefits of agri-environment schemes in five European countries. Ecol Lett 2006; 9: 243-54.

Lamb EG, Bayne E, Holloway G, et al. Indices for monitoring biodiversity change: Are some more effective than others? Ecol Indic 2009; 9: 432-44.

Le Guyader H. La biodiversité : un concept flou ou une réalité scientifique ? Cour Environ 2008; n 55: 7-26. 
Le Roux X, Barbault R, Baudry J, et al. (Eds.) Agriculture et biodiversité. Valoriser les synergies. Expertise scientifique collective, synthèse du rapport, INRA (France), 2008.

Levrel H. Quels indicateurs pour la gestion de la biodiversité. Paris: Institut français de la biodiversité, 2007.

Lindenmayer DB, Likens GE. Direct measurement versus surrogate indicator species for evaluating environmental change and biodiversity loss. Ecosystems 2011; 14: 47-59.

Magurran AE. Measuring biological diversity. Oxford (UK): Blackwell Science, 2004.

Maron P-A, Mougel C, Ranjard L. Soil microbial diversity: Methodological strategy, spatial overview and functional interest. $C R$ Biol 2011; in press.

Marshall EJR, Moonen AC. Field margins in northern Europe: their functions and interactions with agriculture. Agric Ecosyst Environ 2002; 89: 5-21.

Messéan A, Lô-Pelzer E, Bockstaller C, et al. Outils d'évaluation et d'aide à la conception de stratégies innovantes de protection des grandes cultures. Innov Agron 2010; 8: 69-81.

Meyer-Aurich A, Zander P, Hermann M. Consideration of biotic nature conservation targets in agricultural land use - a case study from the Biosphere Reserve SchorfheideChorin. Agric Ecosyst Environ 2003; 98: 529-39.
Meyer BC, Mammen K, Grabaum R. A spatially explicit model for integrating species assessments into landscape planning as exemplified by the Corn Bunting (Emberiza calandra). I Nat Conserv 2007; 15: 94-108.

Millennium Ecosystems Assessment. Ecosystems and Human Well-Being: Synthesis. Washington D.C. (USA): Island Press, 2005.

Noss RF. Indicators for monitoring biodiversity: a hierarchical approach. Conserv Biol 1990; 4: 355-65.

Pacini C, Wossink A, Giesen G, et al. Evaluation of sustainability of organic, integrated and conventional farming systems: a farm and field-scale analysis. Agric Ecosyst Environ 2003; 95: 273-88.

Sadok W, Angevin F, Bergez J-E, et al. Ex ante assessment of the sustainability of alternative cropping systems: guidelines for identifying relevant multi-criteria decision aid methods. Agron Sustain Dev 2008; 28: 163-74.

Sadok W, Angevin F, Bergez J-E, et al. MASC: a qualitative multi-attribute decision model for ex ante assessment of the sustainability of cropping systems. Agron Sustain Dev 2009; 29: 447-61.

Sanderson RA, Rushton SP, Pickering AT, et al. A preliminary method of predicting plant species distributions using the British National Vegetation Classification. J Environ Manage 1995; 43: 265-88.
Sattler C, Nagel UJ, Werner A, et al. Integrated assessment of agricultural production practices to enhance sustainable development in agricultural landscapes. Ecol Indic 2010; 10: 49-61.

Shan Y, Paull D, McKay RI. Machine learning of poorly predictable ecological data. Ecol Model 2006; 195: 129-38.

Straub CS, Snyder WE. Increasing enemy biodiversity strengthens herbivore suppression on two plant species. Ecology 2008; 89: 1605-15.

Tichit M, Barbottin A, Makowski D. A methodological approach to identify cheap and accurate indicators for biodiversity assessment: application to grazing management and two grassland bird species. Animal 2010; 4: 819-26.

Torsvik V, Ovreas L. Microbial diversity and function in soil: from genes to ecosystems. Curr Opin Microbiol 2002; 5: 240-5.

van Wenum J, Buys J, Wossink A. Nature quality indicators in agriculture. In: Brouwer, FM, Crabtree, JR (Eds.), Environmental indicators and agricultural policy. CAB International, Wallingford (UK), 1999.

Vereijken P. A methodical way of prototyping integrated and ecological arable farming systems (I/EAFS) in interaction with pilot farms. Eur J Agron 1997; 7: 235-50. 